\title{
Assessing the nutritional and climatic response of temperate tree species in the Vosges Mountains
}

\author{
Paulina E. PINTO ${ }^{\mathrm{a}, \mathrm{b} *}$, Jean-Claude GÉGOUT ${ }^{\mathrm{a}}$ \\ a Laboratoire d'Étude des Ressources Forêt-Bois, ENGREF, 14 rue Girardet CS 4216, 54042 Nancy Cedex, France \\ b Departamento de Ciencias Forestales, Facultad de Agronomía e Ingeniería Forestal, Pontificia Universidad Católica de Chile, \\ Casilla 306, Correo 22, Santiago, Chile
}

(Received 21 February 2005; accepted 16 June 2005)

\begin{abstract}
Tree species distribution according to climatic gradients is often analysed through geographic information systems modelling whereas their nutrient requirements is mainly studied by experimentation. Using 325 forest plots, this study analysed the response of frequent tree species in the Vosges mountains, a siliceous area in northeast France, along both climate and nutrient gradients. Besides a better understanding of species behaviour, our aim was to investigate if indicator plants can be used to accurately estimate species response to ecological factors. Results showed a main effect of climate on Abies alba and Quercus petraea with a transition between both species around $-20 \mathrm{~mm}$ of June water balance. They also showed a combined effect of climate, base saturation and nitrogen nutrition on Acer pseudoplatanus, Carpinus betulus, Fraxinus excelsior and Pinus sylvestris distribution. Nutritional and climatic variables estimated by Ellenberg indicator values or those established with the phytoecological database EcoPlant are almost as efficient as measured variables to assess tree species ecological response.
\end{abstract}

natural forest / nutrient availability / climate / generalized linear models / ecological niche

Résumé - Effet du climat et de la nutrition minérale sur la distribution des essences dans le massif vosgien. Le lien entre la distribution des essences forestières et les gradients climatiques est souvent analysé à partir de traitements sous système d'information géographique alors que leurs exigences nutritionnelles sont principalement déterminées par expérimentation. À partir de 325 relevés phytoécologiques forestiers, nous analysons dans ce travail la distribution de huit essences fréquentes dans le massif vosgien en prenant en compte simultanément les conditions nutritionnelles et climatiques des sites. En plus d'une meilleure connaissance de l'écologie des essences étudiées, notre objectif est de déterminer si la flore forestière peut être utilisée comme bioindicateur des conditions du milieu pour définir le comportement écologique des essences. Les résultats montrent un fort effet du climat sur Abies alba et Quercus petraea avec une transition entre les deux espèces autour de $-20 \mathrm{~mm}$ de bilan hydrique climatique en juin. Il existe également un effet combiné du climat, du taux de saturation et de la nutrition azotée sur la distribution de Acer pseudoplatanus, Carpinus betulus, Fraxinus excelsior et Pinus sylvestris. Les variables climatiques et nutritionnelles estimées par les valeurs indicatrices d'Ellenberg ou celles calculées à l'aide de la base de données phytoécologiques EcoPlant sont presque aussi efficaces que les variables mesurées pour définir la réponse des essences aux facteurs écologiques.

forêt naturelle / nutrition minérale / climat / modèles linéaires généralisés / niche écologique

\section{INTRODUCTION}

A knowledge of the ecological conditions under which the different tree species occur is an essential pre-requisite for forest management, particularly for the choice of tree species adapted to natural site conditions. In a long-term context, an accurate approach is required in order to ensure that environmental modifications should be taken into account in silvicultural decision-making processes.

Austin et al. [6] pioneered the analytical approach to predict species distribution in relation to a number of environmental factors. Since then, numerous studies have been conducted on species-environment relationships around the world. Guisan and Zimmermann [35] provide an extensive review of those developments which have concerned plant species. Some authors have focused on tree species distribution in relation to ecological variables to elaborate conservation priorities for Australia's Eucalyptus spp. [5]. In addition, frequent evaluations of the effect of climatic change on forest stands have been undertaken, for example: in New Zealand's Nothofagus spp. forests [43], in Canadian boreal forest [45], or in the United States [38, 49]. The studies on global change effects in European temperate forests identify the distribution and behaviour of tree species in relation to climatic variables in the Swiss Alps [11].

\footnotetext{
* Corresponding author: pinto@engref.fr
} 
Nutritional behaviour of European tree species has often been studied using bioindication by plant species. The value of an environmental factor at a site is estimated from Ellenberg species' indicator values [26], or using principal environmental axes from ordination methods [18, 42]. This approach, used in northern Europe, is not as accurate as direct field measurement variables, but has the advantage that soil nutritional variables can be obtained easily and at low cost by plant species bioindication.

Several approaches were also used in Europe by ecologists to describe tree species behaviour according to soil characteristics [21, 22, 25, 47], or to both soil and climatic gradient [26, $41,58,59]$. These authors provide empirical value of tree species optima $[26,41]$ or a graphical display of their tolerance $[58$, 59] according to synthetic gradients of climate, soil moisture or nutrition.

Despite these various studies, the distribution of European tree species according to both climatic and soil resource measured variables has not been studied using an analytical approach. Furthermore, little is known from formalised methods about the ecological behaviour of some tree species (e.g. Carpinus betulus L.), or some areas (west and southwest Europe). A precise knowledge of tree species distribution according to measured variables is important when making an evaluation of species' ecological realized niche, to constitute a guiding framework for silvicultural practices or anticipate tree reaction to global change. Finally, niche evaluation uses either direct variables or estimated variables by bioindication, but there is little information about the relative efficiency of these two approaches.

The Vosges Mountains forests (northeast France) represent an important part of French temperate forest resources, with forest stands characterised by a mixture of coniferous and deciduous tree species, the most frequent being: silver fir (Abies alba L.), European beech (Fagus sylvatica L.), sessile oak (Quercus petraea Liebl.), Norway spruce (Picea abies (L.) Karst.), Scots pine (Pinus sylvestris L.), sycamore (Acer pseudoplatanus L.), ash (Fraxinus excelsior L.) and hornbeam (Carpinus betulus L.). Forests of this area are particularly characteristic of the transition between colline deciduous sessile oak-European beech stands and montane mixed silver fir-European beech stands, which to date has not been studied. With both nutritional and altitudinal gradients, this natural area provides the species and environmental diversity useful for studying ecological behaviour of tree species and communities.

The purpose of this paper is to: (1) identify the chemical (soil conditions) and physical (climatic) variables that most strongly influence tree species composition in the forests of the Vosges Mountains; (2) estimate the response of tree species according to the main environmental factors; (3) compare the efficiency of plant bioindication and measured variables to explain stand composition, with the objective of making an easy assessment of environmental conditions.

\section{MATERIALS AND METHODS}

\subsection{Study area and data sources}

The study area is limited to the crystalline Vosges Mountains, in northeastern France, located between $47^{\circ} 33^{\prime}$ to $48^{\circ} 47^{\prime}$ latitude and $5^{\circ} 50^{\prime}$ to $7^{\circ} 28^{\prime}$ longitude. The delimitation, based on the geological substrates, allowed us to establish a continuous study area with homogeneous geology and geomorphology. This natural region of $6800 \mathrm{~km}^{2}$ comprises a wide altitude range ( 400 to $1400 \mathrm{~m}$ ) and a significant variability in soil nutrient status $\left(3<\mathrm{pH}-\mathrm{H}_{2} \mathrm{O}\right.$ of A-horizon of soil $\left.<7\right)$ [29]. 325 plots located within this study area were extracted from EcoPlant, a forest sites database with complete floristic relevé and both climatic and measured soil nutritional variables available on each plot [32]. All these plots were sampled in mature natural forest stands of native species mainly composed of silver fir, European beech, sessile oak, Norway spruce, Scots pine and sycamore. For each sample plot, the presence of all vascular species and terricolous bryophytes was recorded over a surface area of $400 \mathrm{~m}^{2}$. Two categories of species were distinguished in each plot: (i) tree species, divided into overstory (tree species taller than $7 \mathrm{~m}$ ) and understory (tree species smaller than $7 \mathrm{~m}$, excluding tree seedling) layers; (ii) shrubs, herbaceous species, and bryophytes.

\subsection{Measured ecological variables}

Soil nutrient resources were evaluated in the field through humus form description, a ground variable highly correlated with the soil nutrient regime [12, 23, 39]. Humus forms were grouped in five categories (dysmoder and eumoder, hemimoder and dysmull, oligomull, mesomull, eumull) [13]. In each plot, one soil sample was collected in the A-horizon for laboratory analyses. Soil samples were air-dried and sieved at $2 \mathrm{~mm}$. Exchangeable $\mathrm{Ca}, \mathrm{K}, \mathrm{Mg}$ and $\mathrm{Al}$, were extracted with $0.5 \mathrm{M} \mathrm{NH}_{4} \mathrm{Cl}$ at soil $\mathrm{pH}$ and measured by spectrometry. Protons were measured by titration. Base Saturation (BS) was defined as $\left(\mathrm{Ca}^{++}+\mathrm{Mg}^{++}+\mathrm{K}^{+}\right) /\left(\mathrm{Ca}^{++}+\mathrm{Mg}^{++}+\mathrm{K}^{+}+\mathrm{Al}^{+++}+\mathrm{H}^{+}\right)$ratio. $\mathrm{pH}-\mathrm{H}_{2} \mathrm{O}$ was measured, after 1:2.5 dilution of fine earth, with $\mathrm{pH}$-electrodes. Total nitrogen and organic carbon were measured using the Kjeldahl and Anne methods.

Climatic variables came from AURELHY, a $1 \mathrm{~km}$ gridded temperature and precipitation model which extends over France and takes into account the effect of altitude [9]. Data consists of 1961-1990 monthly mean precipitation $(\mathrm{P})$ and monthly minimum, maximum and mean temperature (respectively: Tmin, Tmax, T). These variables allowed us to calculate climatic variables used successfully to explain plant species distribution such as monthly Thornthwaite potential evapotranspiration (PET) [67], monthly climatic water balance (e.g. $\mathrm{WB}_{\text {June }}=\mathrm{P}_{\text {June }}-\mathrm{PET}_{\text {June }}$ ) and De Martonne monthly aridity index (e.g. $\left.\mathrm{AI}_{\text {June }}=\mathrm{P}_{\text {June }} /\left(\mathrm{T}_{\text {June }}+10\right)\right)[17]$. This index, low when the aridity is high, has been used to explain tree species distribution $[51,61]$.

\subsection{Predicted variables}

The environmental variables were also estimated for each plot using plant species indicator values (IV). Ellenberg's indicator values were used to estimate three soil factors: moisture $(F)$, reaction $(\mathrm{R})$ and soil nitrogen availability $(\mathrm{N})$ [26]. These values were assigned empirically on the basis of observations and measurements, and express the relative response of plant species in their natural environment as compared to other species. They have been successfully used in Northern Europe, Great Britain, Germany, Eastern Europe and the Mediterranean region to estimate environmental variables using vegetation (see [19]).

A formalized method to assess species IV was proposed by Ter Braak and Looman [65]. Under the hypothesis of an unimodal response of species to environmental variables, the presence probability curve of a species along any variable is modelled using logistic regression and the indicator value is defined as the value of the variable that maximises the presence probability of the species [64, 65]. Using this method the indicator values of the 700 most frequent plant species in French forests have been established for three nutritional and three 
climatic variables [31]. Four thousands plots from EcoPlant, with complete plant species inventory, measured soil variables and modelled climatic variables were used to assess response curves and indicator values of these plant species according to: $\mathrm{pH}$ as an acidity variable $\left(\mathrm{IV}_{\mathrm{pH}}\right), \mathrm{C}: \mathrm{N}$ ratio as a nitrogen availability variable $\left(\mathrm{IV}_{\mathrm{C}: \mathrm{N}}\right)$, base saturation as a mineral nutrition/toxicity variable ( $\left.\mathrm{IV}_{\mathrm{BS}}\right)$, mean annual temperature as a variable linked to growth, mean January temperature as a variable of winter conditions and the De Martonne annual index of aridity $\left(\mathrm{IV}_{\mathrm{AI}}\right)$.

For the two sets of indicator values, estimation of variables using plant species was based on the classical IVs approach, that consists in calculating mean IVs of the species present in the plot [26]. Only shrub, herbaceous species and bryophytes were considered. Forest tree species were excluded in order to ensure the independence of the response variable and the explanatory variables.

\subsection{Multivariate analyses of vegetal communities}

Two correspondence analyses (CA) were used to identify soil resources and climatic variables that have the greatest influence on tree species and other plant species communities respectively. CA were run on presence/absence species-by-plots tables with species present in more than $1 \%$ of the plots. The CA of tree species $\left(\mathrm{CA}_{\mathrm{T}}\right)$ was run with 16 different tree species divided into two layers: overstory and understory tree species. The analysed data matrix, $T$, was constituted with 325 rows (plots) and 30 columns. The $\mathrm{CA}$ of shrubs, herbaceous species and bryophytes $\left(\mathrm{CA}_{\mathrm{SHB}}\right)$ was run with the same 325 plots and 110 species in one layer. CA showed no arch effects that justify not using detrended correspondence analysis [66, 70].

Based on the hypothesis that environmental factors control the distribution of species and communities, the ecological interpretation of CA ordination axes was assessed by (multiple) linear regressions between plot scores and plot nutritional and climatic variables [57, 66].

Four canonical correspondence analyses (CCA) [63] were used as a direct means of explaining stand composition, according to soil nutrient availability and climatic variables. For each CCA, the data analysed were present in two tables: (i) the presence/absence tree species-by-plots table, $T$, with $n$ rows $(n=325)$ and $p$ columns $(p=30)$; (ii) the ecological table, $E$, with $n$ rows and $q$ columns: the $i$ th row in $E$ as well as in $T$ correspond to the same plot, each column in $E$ correspond to an ecological measured or estimated variable. In order to compare the efficiency of measured variables and plant indicator variables, CCA was performed on four pair of tables $T$ (unchanged) and $E$, where four different series of environmental variables were selected: $E_{1}$, measured variables: $\mathrm{BS}, \mathrm{C}: \mathrm{N}$ ratio and $\mathrm{WB}_{\mathrm{June}} ; E_{2}$, plot scores on $\mathrm{CA}_{\mathrm{SHB}}$ for axis 1 and axis $2 ; E_{3}$, EcoPlant indicator values estimations: $\mathrm{IV}_{\mathrm{C}: \mathrm{N}}, \mathrm{IV}_{\mathrm{BS}}, \mathrm{IV}_{\mathrm{AI}} ; E_{4}$, Ellenberg indicator values estimations: $\mathrm{R}, \mathrm{F}$ and $\mathrm{N}$.

As shown by Lebreton et al. [44] and Gégout and Houllier [30], the following ratio can be used as a means of assessing the relative efficiency of CCA versus CA:

$$
e_{m}=\sum_{k=1}^{m} \lambda_{C C A, k} / \sum_{k=1}^{m} \lambda_{C A, k} \leq 1
$$

where, $\lambda$ is the eigenvalue associated to the $k$ th ordination axis of CCA or CA and $e_{m}$ can be considered as the empirical index that measures the efficiency of the ecological variables used in $E$ for predicting the composition of the vegetation. The closer the eigenvalues of the $m$ first axes of CCA are to the $m$ first axes of CA, the greater the efficiency of environmental variables and the closer $e_{m}$ is to 1 . The efficiency of the different sets of environmental variables to explain tree composition of plots was achieved by means of this $e_{m}$ ratio.

\subsection{Modelling of tree species behaviour}

The ecological response of the eight most frequent tree species was derived from multiple logistic regression models [65]. Logistic regression is a generalized linear modelling approach [48], with a logit link function and binomial error distribution, and is one of the most popular models for characterizing species presence/absence as a function of environment $[4,35]$. The goal of logistic regressions was to define the environmental response of the most frequent tree species in the Vosges natural forest, according to the key environmental predictors explaining stand composition and tree species distribution. The probability of occurrence of each tree species was determined using the 4 sets of ecological variables used in the CCA, either measured directly or estimated by plant species. For all variables of each set $\left(E_{1}, E_{2}, E_{3}, E_{4}\right)$, we tested the significance (at the 0.05 level) of the Gaussian logit model (bell-shaped unimodal response curve) against the linear logit model (increasing or decreasing sigmoidal response curve), or against the null model (no reaction and flat response curve). A residual deviance test, based on the Akaike Information Criterion (AIC) [1], was then achieved for all the significant models including one or several variables simultaneously. The selected model, for each of the 4 sets of variables, was the one that minimized AIC. All computations were performed with S-PLUS 2000 statistical package [46].

Based on the resulting logistic regression equations we then could model the response surface for each tree species. This shape is a first approximation to define the environmental behaviour of tree species according to both nutritional and climatic factors.

\section{RESULTS}

\subsection{CA of tree species and gradient interpretations}

The first two axes of tree species CA have a significant ecological meaning. A strong correlation was observed between the first axis and nutritional variables, either base saturation or C:N ratio (Tab. I). The multiple regression model including both variables demonstrated that this major gradient is a mineral and nitrogen resources gradient $\left(R^{2}=0.50 ; p<0.0001\right.$ or $R^{2}=0.61 ; p<0.0001$ with integration of humus forms), ranging from oligotrophic forests with low BS values and a high C:N ratio to forests with good nutrient availability, high BS and a low C:N ratio. According to this gradient, coniferous species, especially Pinus sylvestris, are present on the oligotrophic soils, as opposed to Acer spp., Fraxinus excelsior and more generally broadleaved species that occur on rich soils (Fig. 1).

Axis 2 is correlated with summer water availability mainly represented by water balance of June $(r=0.66 ; p<0.0001)$ and aridity index of June $(r=0.64 ; p<0.0001)$. Its link with temperature variables or elevation is less important (Tab. I). Axis 2 covers a vegetation moisture gradient ranging from low water availability and elevation with Quercus petraea, Carpinus betulus and Castanea sativa to humid forest stands with Acer spp. and Picea abies (Fig. 1).

\subsection{CA of other plant species communities and ecological interpretation}

Although not presented in detail, the CA concerning shrubs, herbaceous species and bryophytes $\left(\mathrm{CA}_{\mathrm{SHB}}\right)$ also showed two axes with a clear ecological meaning. Species known to occur on oligotrophic soils, like Vaccinium myrtillus, Deschampsia 
Table I. Correlation coefficients between environmental variables and $\mathrm{CA}$ plot scores for: $\mathrm{CA}_{\mathrm{T}}$, correspondence analysis of tree species; $\mathrm{CA}_{\mathrm{SHB}}$, correspondence analysis of shrubs, herbaceous species and bryophytes. $\mathrm{T}$, mean temperature; $\mathrm{P}$, mean precipitation. Bold indicates variables included in the multiple regression models. n.s., non-significant at $p<0.0001$.

\begin{tabular}{|c|c|c|c|c|}
\hline \multirow{2}{*}{ Variable } & \multicolumn{2}{|c|}{$\mathrm{CA}_{\mathrm{T}}$} & \multicolumn{2}{|c|}{$\mathrm{CA}_{\mathrm{SHB}}$} \\
\hline & Axis 1 & Axis 2 & Axis 1 & Axis 2 \\
\hline \multicolumn{5}{|l|}{ Nutritional: } \\
\hline Base Saturation & 0.65 & n.s. & 0.74 & n.s. \\
\hline $\ln (\mathrm{Ca})$ & 0.60 & n.s. & 0.75 & n.s. \\
\hline $\ln (\mathrm{Mg})$ & 0.58 & n.s. & 0.58 & n.s. \\
\hline $\ln (\mathrm{K})$ & 0.33 & n.s. & 0.28 & n.s. \\
\hline $\ln (\mathrm{Al})$ & -0.52 & n.s. & -0.51 & 0.27 \\
\hline $\ln (\mathrm{H})$ & -0.48 & n.s. & -0.57 & 0.23 \\
\hline $\mathrm{pH}$ & 0.58 & n.s. & 0.59 & -0.34 \\
\hline $\mathrm{C}: \mathrm{N}$ ratio & -0.52 & n.s. & -0.63 & n.s. \\
\hline Eumull humus form & 0.66 & n.s. & 0.47 & -0.34 \\
\hline Dysmoder-Eumoder humus form & -0.42 & n.s. & -0.57 & n.s. \\
\hline \multicolumn{5}{|l|}{ Climatic: } \\
\hline Elevation & n.s. & 0.59 & n.s. & 0.60 \\
\hline Water balance of June & n.s. & 0.66 & n.s. & 0.53 \\
\hline Aridity index of June & n.s. & 0.64 & n.s. & 0.53 \\
\hline $\mathrm{P}$ annual & n.s. & 0.52 & n.s. & 0.26 \\
\hline P June & n.s. & 0.64 & n.s. & 0.46 \\
\hline T annual & n.s. & -0.59 & n.s. & -0.63 \\
\hline
\end{tabular}

flexuosa, Calluna vulgaris or the bryophytes Bazzania trilobata and Leucobryum glaucum, had low scores on the first CA axis. In contrast, nutrient-demanding species, like Geum urbanum, Primula elatior, Mercurialis perennis or Euphorbia amygdaloides had positive scores on this axis. Multiple regression analyses between environmental variables and plot scores (Tab. I) revealed that the first gradient was greatly determined by base saturation and C:N ratio $\left(R^{2}=0.67 ; p<0.0001\right)$ with humus form offering complementary information $\left(R^{2}=0.70\right.$; $p<0.0001$ for the model with $\mathrm{BS}, \mathrm{C}: \mathrm{N}$ ratio and humus forms).

As for tree species' $\mathrm{CA}$, the second axis of $\mathrm{CA}_{\mathrm{SHB}}$ was correlated to climatic factors (Tab. I). It showed a gradient from colline to montane species such as Rumex arifolius, Lonicera nigra, Adenostyles alliariae or Cicerbita alpina. However, as opposed to tree species results, plot scores here were more correlated to temperature $\left(R^{2}=0.40\right.$ with T annual; $\left.p<0.0001\right)$ than to water-related variables $\left(R^{2}=0.28\right.$ with $\mathrm{WB}_{\text {June }} ; p<$ $0.0001)$.

\subsection{CCA and effect of main ecological variables on stand composition}

The CCA used with measured ecological variables $\left(E_{1}\right)$ confirmed the importance of both nutrient and water availability factors to explain the composition of tree communities (Tab. II). The first ordination axis was a mineral and nitrogen nutrient gradient, fairly similar to the first axis of CA $\left(e_{1}=0.62\right.$

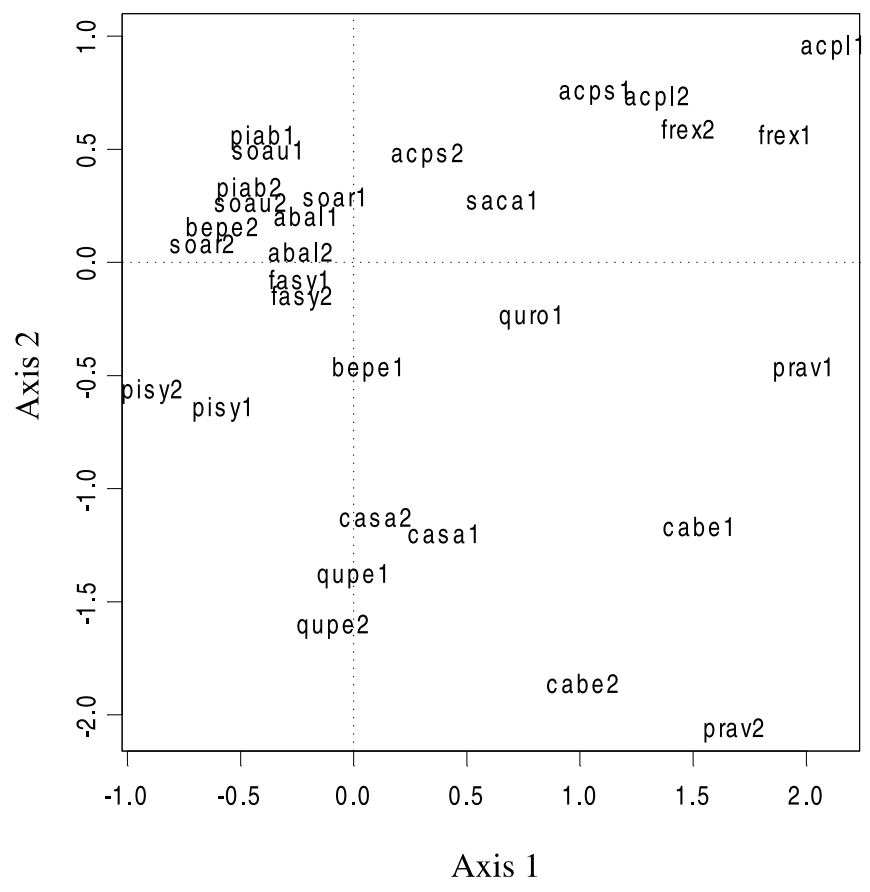

Figure 1. Tree species on correspondence analysis $\left(\mathrm{CA}_{\mathrm{T}}\right)$ ordination diagram 1-2. Tree species abbreviations: 1 , tree layer; 2 , understory tree layer; abal, Abies alba; acpl, Acer platanoides; acps, Acer pseudoplatanus; bepe, Betula pendula; cabe, Carpinus betulus; casa, Castanea sativa; fasy, Fagus sylvatica; frex, Fraxinus excelsior; piab, Picea abies; pisy, Pinus sylvestris; prav, Prunus avium; qupe, Quercus petraea; quro, Quercus robur; saca, Salix caprea; soar, Sorbus aria; soau, Sorbus aucuparia.

Table II. Efficiency of measured variables $\left(E_{1}\right)$ and estimated variables by indicator plants $\left(E_{2}, E_{3}, E_{4}\right)$ to predict tree species composition.

\begin{tabular}{llcccc}
\hline Analyses & Constrain variables & \multicolumn{2}{c}{ Eigenvalue } & \multicolumn{2}{c}{$\begin{array}{c}\text { Efficiency } \\
\text { index }\end{array}$} \\
& & $\lambda_{1}$ & $\lambda_{2}$ & $e_{1}^{*}$ & $e_{2}{ }^{*}$ \\
\hline $\mathrm{CA}_{\mathrm{T}}$ & 0.41 & 0.36 & & \\
$\mathrm{CCA}$ on $\left(\mathrm{T}, \mathrm{E}_{1}\right)$ & $\mathrm{BS}, \mathrm{C}: \mathrm{N}$ ratio, $\mathrm{WB}_{\mathrm{June}}$ & 0.25 & 0.19 & 0.62 & 0.57 \\
$\mathrm{CCA}$ on $\left(\mathrm{T}_{2}\right)$ & $\mathrm{CA}_{\mathrm{SHB}}$ axis $1, \mathrm{CA}_{\mathrm{SHB}}$ axis 2 & 0.27 & 0.14 & 0.65 & 0.53 \\
$\mathrm{CCA}$ on $\left(\mathrm{T}_{2}\right)$ & $\mathrm{IV}_{\mathrm{BS}}, \mathrm{IV}_{\mathrm{C}: \mathrm{N}}, \mathrm{IV}_{\mathrm{AI}}$ & 0.26 & 0.14 & 0.64 & 0.51 \\
$\mathrm{CCA}$ on $\left(\mathrm{T}, \mathrm{E}_{4}\right)$ & $\mathrm{R}, \mathrm{N}, \mathrm{F}$ & 0.25 & 0.12 & 0.61 & 0.48 \\
\hline
\end{tabular}

* See formula (1).

with measured variables). The second CCA axis, linked to $\mathrm{WB}_{\text {June, }}$, clearly accounted for summer water availability and also confirmed the gradient obtained with the CA $\left(e_{2}=0.57\right)$.

The CCA ordination diagram provides an overview of tree species behaviour according to measured soil resources (BS and $\mathrm{C}: \mathrm{N}$ ratio) and climatic variables ( $\mathrm{WB}_{\text {June }}$ ) (Fig. 2). Five tree species are found in the driest conditions. The arrangement of these species along the nutrient gradient (axis 1) ranged from Pinus sylvestris through Quercus petraea, Castanea sativa and Carpinus betulus to Prunus avium. Only one species, Sorbus aucuparia (in the tree strata) is found at the highest WB values. It is always found, in the tree layer, at more than $800 \mathrm{~m}$ in 


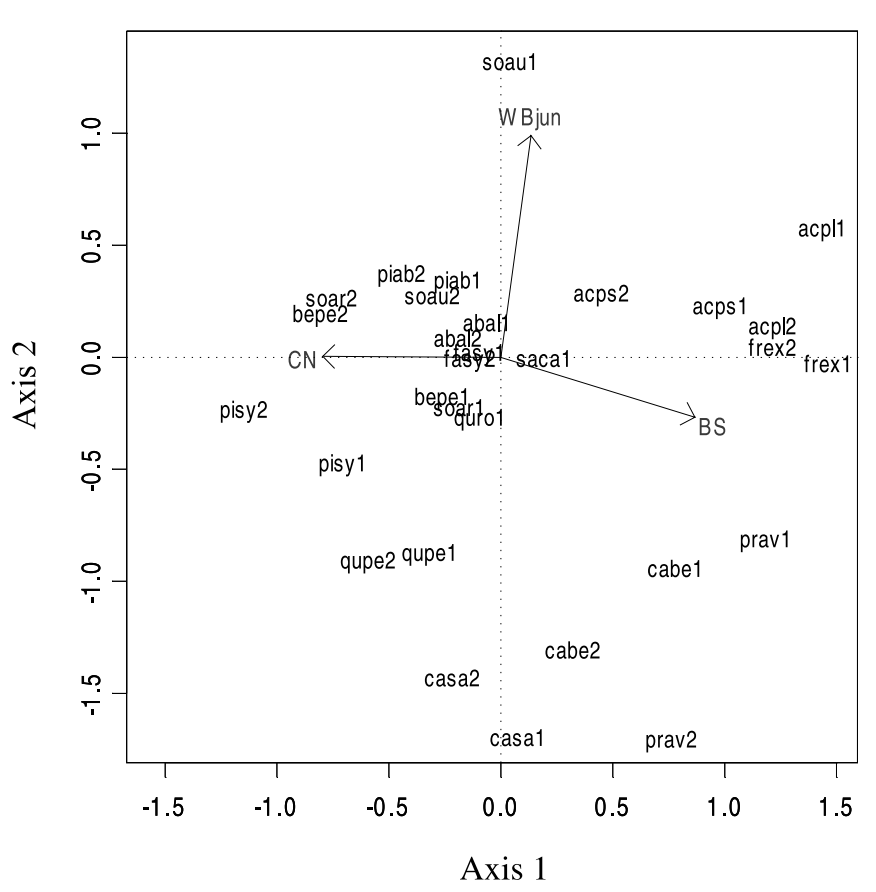

Figure 2. Tree species on CCA ordination diagram 1-2. (see Fig. 1 legend for abbreviations).

elevation with annual rainfall above $1450 \mathrm{~mm}$ and often found among the timberline species. For other favourable WB conditions (null values for axis 2 and middle elevation forests), Acer pseudoplatanus, Acer platanoides and Fraxinus excelsior occur in fertile soils and Abies alba, Fagus sylvatica and Picea abies are found in more acidic soils. Compared to CA, Quercus robur and Salix caprea seemed to move towards more acidic soils in CCA and Sorbus aria and Castanea sativa moved to more extreme water balance conditions. These four species are poorly represented in the data set (frequency $<10$ ) and their ecological requirements cannot be specified accurately.

In order to investigate the relevance of ground vegetation as surrogate of measured variables, the first two axes of the $\mathrm{CA}_{\mathrm{SHB}}$ were used in CCA as environmental variables to explain tree stand composition. Estimated nutritional and climatic variables with species indicator values for Central
Europe (Ellenberg IV) and indicator values from the EcoPlant database, respectively, were also used as instrumental variables in CCA. According to CCA results reported in Table II, the prediction quality of tree species composition according to both nutrient (axis 1) and climatic gradient (axis 2), allowed of rank the 4 groups of predictors as follows for axis 1: CA $A_{\text {SHB }}$ Axis 1-2 > EcoPlant IV $>$ measured variables $>$ Ellenberg IV; for axis $1+2$ : measured variables $>\mathrm{CA}_{\mathrm{SHB}}$ Axis 1-2 $>$ EcoPlant IV $>$ Ellenberg IV. Differences between methods are not important and as compared to variables measured directly, variables estimated by plant species showed similar efficiency to predict tree species composition.

\subsection{Nutritional and climatic behaviour of main tree species}

The behaviour of the 8 most frequent tree species in the Vosges Mountains - silver fir, European beech, Norway spruce, sessile oak, Scots pine, sycamore, hornbeam and ash - was modelled with logistic regression according to the three main environmental variables determining the distribution of tree species: measured base saturation, $\mathrm{C}: \mathrm{N}$ ratio and June water balance (Tab. III).

Three tree species - Scots pine, Norway spruce and especially European beech - did not appear to be strongly linked to the variables studied. The opposite was clearly observed for sycamore, hornbeam, ash and sessile oak that occur only in a narrow range of ecological conditions in the Vosges Mountains (Tab. IV).

As shown in Figure 3, Norway spruce, sessile oak and Scots pine are frequent on oligotrophic sites (low BS values), Norway spruce in wet sites, and sessile oak and Scots pine in dry conditions. The occurrence probability of this last species was highest in the worse conditions of mineral, nitrogen and water availability. European beech and silver fir prefer intermediate nitrogen availability. However, both species have low nutritional requirements, as evidenced by their high probability of occurrence along the whole nutrient gradient. European beech is present along the full WB gradient, while silver fir presents a quadratic response with a preference for sites where $\mathrm{WB}_{\text {June }}$ is positive. In hornbeam, ash and sycamore models, the nutritional factor (BS) was highly significant (Tab. III). These tree

Table III. Coefficient of logit models predicting the occurrence of main tree species in the Vosges Mountains, according to measured environmental variables. BS is base saturation; $\mathrm{C}: \mathrm{N}$ is $\mathrm{C}: \mathrm{N}$ ratio and WB is June Water Balance. Max. $p$ is the maximum probability value of the $t$ statistic associated to the variables.

\begin{tabular}{|c|c|c|c|c|c|c|c|c|}
\hline \multirow[t]{2}{*}{ Species } & \multicolumn{7}{|c|}{ Terms of model suggested } & \multirow[t]{2}{*}{$\operatorname{Max} p$} \\
\hline & Intercept & BS & $\mathrm{BS}^{2}$ & $\mathrm{C}: \mathrm{N}$ & $\mathrm{C}: \mathrm{N}^{2}$ & WB & $\mathrm{WB}^{2}$ & \\
\hline Abies alba & -6.3297 & 0.0153 & & 0.5768 & -0.0112 & 0.0310 & -0.0008 & $<0.01$ \\
\hline Acer pseudoplatanus & -0.2637 & 0.0268 & & -0.1784 & & 0.0218 & & $<0.01$ \\
\hline Carpinus betulus & 1.8667 & 0.0165 & & -0.3216 & & -0.0737 & -0.0012 & $<0.05$ \\
\hline Pinus sylvestris & -3.6536 & -0.0187 & & 0.1219 & & -0.0304 & & $<0.05$ \\
\hline Picea abies & -0.2577 & -0.0150 & & & & 0.0195 & & $<0.01$ \\
\hline Quercus petraea & -0.8093 & -0.0137 & & & & -0.0699 & & $<0.05$ \\
\hline Fraxinus excelsior & 1.2048 & 0.0388 & & -0.4002 & & & & $<0.01$ \\
\hline Fagus sylvatica & -3.6276 & & & 0.4223 & -0.0093 & & & $<0.01$ \\
\hline
\end{tabular}


Table IV. Akaike Information criteria (AIC) of models predicting the occurrence of tree species (tree layer) in the study area. Four models are shown by tree species in relation to different predicted variables used: measured variables (BS, $\mathrm{C}: \mathrm{N}$ ratio, $\mathrm{WB}_{\text {June }}$ ); locally estimated variables by plant species $\left(\mathrm{CA}_{\mathrm{H}^{-}}\right.$-axis $1, \mathrm{CA}_{\mathrm{H}^{-}}$axis 2$)$; estimated variables by EcoPlant IV $\left(\mathrm{IV}_{\mathrm{BS}}, \mathrm{IV}_{\mathrm{C}: \mathrm{N}}, \mathrm{IV}_{\mathrm{AI}}\right)$; estimated variables by Ellenberg IV (R, $\mathrm{N}, \mathrm{F})$.

\begin{tabular}{|c|c|c|c|c|c|}
\hline \multirow{3}{*}{ Species } & \multirow{3}{*}{ Deviance null model } & \multicolumn{4}{|c|}{ * AIC of models according to predicted variables } \\
\hline & & \multirow{2}{*}{$\begin{array}{c}\text { Measured } \\
\text { variables }\end{array}$} & \multicolumn{3}{|c|}{ Estimated variables } \\
\hline & & & $\mathrm{CA}_{\mathrm{SHB}}$ Axes & EcoPlant IV & Ellenberg IV \\
\hline Abies alba & 448 & 43.4 & 41.1 & 41.3 & 31.0 \\
\hline Acer pseudoplatanus & 299 & 65.4 & 68.8 & 64.2 & 67.9 \\
\hline Carpinus betulus & 195 & 51.5 & 91.8 & 80.3 & 40.0 \\
\hline Fagus sylvatica & 421 & 8.1 & 11.8 & 15.1 & 13.7 \\
\hline Fraxinus excelsior & 209 & 79.4 & 92.2 & 84.9 & 86.7 \\
\hline Picea abies & 420 & 23.8 & 18.0 & 25.8 & 32.9 \\
\hline Pinus sylvestris & 242 & 29.4 & 23.9 & 25.3 & 22.7 \\
\hline Quercus petraea & 367 & 97.4 & 73.2 & 78.7 & 83.6 \\
\hline
\end{tabular}

$*$ AIC $=$ Null deviance - Residual deviance $-2 \times$ (number of parameters).

species preferred sites with high levels of exchangeable base cations $(\mathrm{Ca}, \mathrm{Mg}, \mathrm{K}$ ), favourable nitrogen nutrition (low $\mathrm{C}: \mathrm{N}$ ratio) and low Al toxicity. Sycamore, at lower elevations (lower values of $\mathrm{WB}$ ) was only predicted at rich sites (BS $>80 \%$ ), while its presence was predicted throughout the entire range of $\mathrm{BS}$ at the highest elevations ( $>1000 \mathrm{~m}$, high WB) with the highest values of occurrence probability in highest nutrient availability sites. With the same preference for a favourable nutrient supply, hornbeam is located on more dry sites. Ash clearly has the narrowest nutrient availability range: it occurs only when $\mathrm{BS}>30 \%$ and $\mathrm{C}: \mathrm{N}$ ratio $<15$ (Fig. 3).

Although not present in detail, the models obtained with estimated variables based on vegetation provided similar results to those found with measured variables: the positive or negative effect of significant variables was the same for both types of model. Differences were observed due to the ecological meaning of climatic variables: for example, climatic variables had a significant effect (at $0.01 p$-level) on the sycamore occurrence model only when they clearly indicated a climatic water availability gradient (measured WB and EcoPlant IV for aridity index). A thermic gradient (axis 2 of $\mathrm{CA}_{\mathrm{SHB}}$ ) or a soil moisture gradient ( $\mathrm{F}$ value of Ellenberg) did not have any significant effect on the response curve of this species. Furthermore, models do not always incorporate the same nutritional variables: nitrogen availability assessed by vegetation was thus significant in the 8 tree species models whereas measured $\mathrm{C}: \mathrm{N}$, as shown in Table III, was significant for 6 species.

Table IV shows the efficiency, based on the Akaike Information Criterion (AIC), of measured variables and plant indicator variables to model tree species occurrence. Clear differences between measured variables and those estimated by plant species predictors were only obtained for Quercus petraea and Fraxinus excelsior, while for the 5 species Abies alba, Fagus sylvatica, Picea abies, Pinus sylvestris and Acer pseudoplatanus, both methods gave equivalent results. As compared with measured variables, the results for Carpinus betulus are clearly better for EcoPlant IV and CA plot scores while Ellenberg IV showed worse results.

\section{DISCUSSION}

\subsection{Factors determining species occurrence}

Gradient analyses carried out in our study to determine ecological factors responsible for shrub, herbaceous and bryophytes composition showed a first gradient correlated with both nitrogen nutrition (evaluated by $\mathrm{C}: \mathrm{N}$ ratio) and soil base saturation that is a direct measure of exchangeable cation pools. This result confirmed the importance of changing soil properties along the acid-base gradient with nitrogen nutrition, aluminium and proton toxicity influencing the composition of European forest plant communities [27], previously observed in Norway [24], Sweden [14, 20], Britain [28], Denmark [34], and northern Germany [37]. Furthermore, our study showed that the same direct nutritional factors also explain the main gradient of tree species distribution of mature deciduous, mixed or coniferous forests in the Vosges Mountains. It completes previous investigations that have shown a link between tree species and indirect soil-related variables, such as geology or soil types $[55,60]$. However, our results could be more detailed with the integration of other nutritional variables such as phosphorus, which has been determinant to species distribution in other areas $[24,50]$. Complementary investigations could also be carried out with direct measures of mineralization rates of $\mathrm{N}$, such as incubation methods that are probably better indicators of $\mathrm{N}$ availability than $\mathrm{C}: \mathrm{N}$ ratio.

The weaker relationship between nutritional factors and tree species composition as compared to the relationship linking nutritional factors to other plant species can probably be accounted for by silvicultural practices that influence stand composition. As plantations were avoided in this study, silvicultural practices could only modify stands by selective cutting that decreases the occurrence probability of tree species. However, under the reasonable assumption of homogeneous practices along ecological gradients, this does not modify their ecological optimum, but reduces the ecological interpretation and the projected dispersion on the CCA axes. On the other 
(a) Abies alba

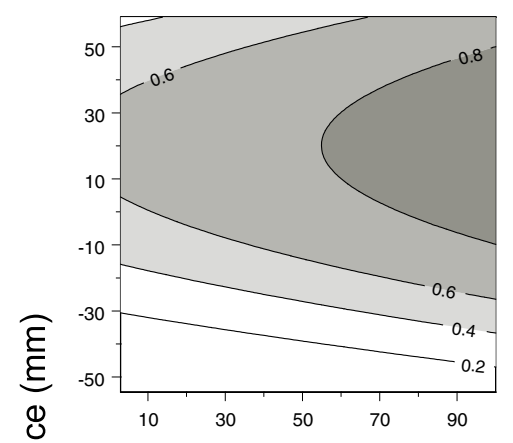

(a) Pinus sylvestris

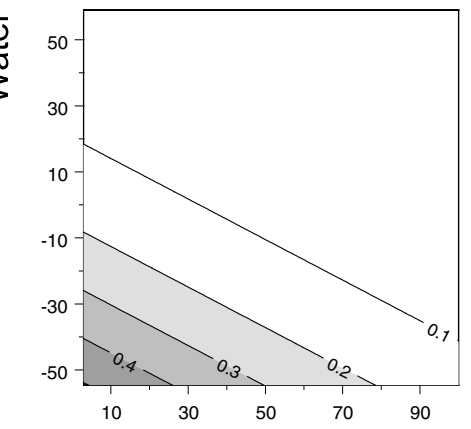

(a) Acer pseudoplatanus

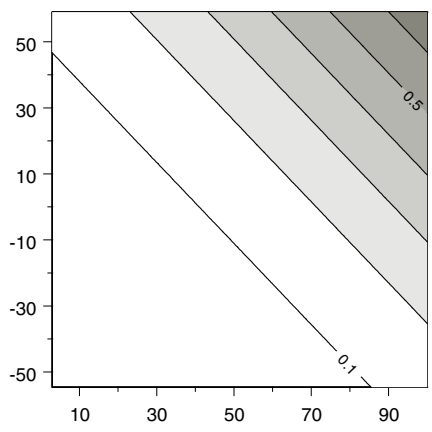

(b) Picea abies



(a) Carpinus betulus

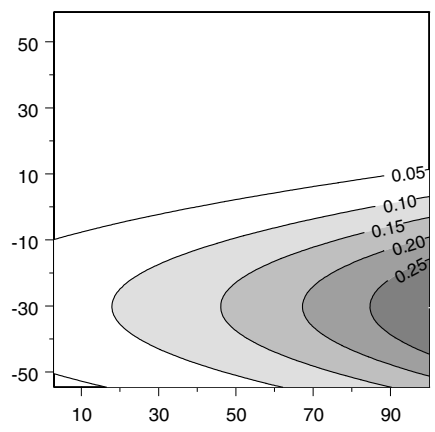

(b) Quercus petraea

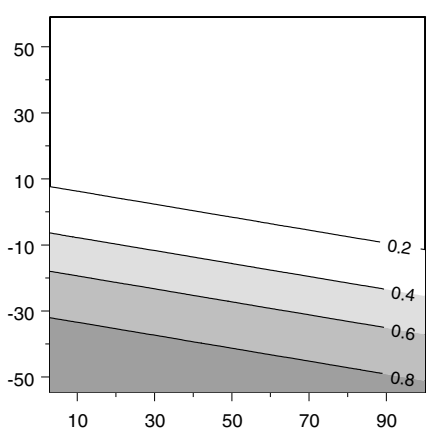

Base Saturation (\%)

(c) Fraxinus excelsior

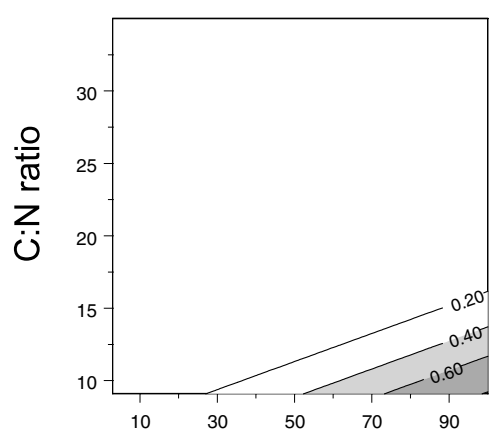

(d) Fagus sylvatica



Base Saturation (\%)

Figure 3. Predicted probability of occurrence for eight tree species according to main ecological factors structuring tree species composition. (a) models with Base Saturation (BS), C:N ratio and June Water Balance (WB June) where C:N ratio = 17; (b) models with Base Saturation and June Water Balance (WB June); (c) model with Base Saturation (BS) and C:N ratio; (d) model with C:N ratio.

hand, the better relationship between the composition of shrubs, herbaceous species and bryophytes and the nutritional variables measured at the A-horizon may be due to their higher dependence on upper horizon nutrition than for tree species. Their root system is, in fact, not very deep in relation to that of tree species.

The other main gradient for both trees and other plant species composition is related to climatic variables. The relevance of these variables to vegetation composition was always shown in mountainous areas $[10,55]$. With separate analyses of trees and other plant species on the same set of plots, we showed that water availability was the main climatic factor determining tree species, while it was temperature for shrubs, herbaceous species and bryophytes. This difference is consistent with the higher water requirements of tree species as compared to those of shrubs, herbaceous species and bryophytes, and it is probable that water availability is a stronger limiting factor for tree species than for herbaceous species. The evaluation of soil water 
content available for roots is difficult to measure on a great number of plots, but the taking into account of this variable in addition to climate could improve the modelling of tree species distribution.

\subsection{Ecological response of tree species}

The ecological response of tree species showed, for the entire nutritional range, the decreasing occurrence of silver fir and a simultaneous increase in the occurrence of sessile oak below -10 to $-30 \mathrm{~mm}$ WB deficit in June. These values give the transition between sessile oak- European beech forest in the colline zone and silver fir-European beech forest in the mountain zone. Cachan [15], confirmed by the AURELHY model of Météo France, showed for the Vosges mountains that precipitation values are higher in the west of the mountain crest than in the eastern side, leading at a value of $-20 \mathrm{~mm}$ of WB deficit in June for $400 \mathrm{~m}$ of altitude in the west side of the crest and $550 \mathrm{~m}$ of altitude in the east side. Similar transitions took place for the same level of WB on oligotrophic soils between Scots pine at low altitude and Norway spruce, and on nutrient-rich soils between hornbeam at low altitude and sycamore at high altitude. The relevant factors and limit values that control these transitions must be verified in a larger geographical and ecological context. In the Swiss Alps, for example, European beech and silver fir seemed to have similar water balance requirements [11], while at low values of WB in the Vosges Mountains, European beech extends with sessile oak in the absence of silver fir.

Conifers, European beech and sessile oak occur on soils with low BS values in the Vosges Mountains, as compared to hornbeam, ash and sycamore that require fertile sites. The high nutrient requirements of ash were observed in other field studies of realized niche, carried out in Sweden [18] and in Denmark [42]. These different nutrient requirements between species are consistent with experiments carried out to analyse Al toxicity or $\mathrm{Ca}, \mathrm{Mg}$ deficiency effects $[62,71]$. They are also consistent with the nutrient contents of tree species: higher for the most nutrient demanding species such as sycamore, hornbeam and ash than for low relative nutrient requirement species such as Scots pine or Norway spruce [2, 3, 36, 56]. Because of their lower nutrient requirements, Scots pine and Norway spruce can endure more oligotrophic conditions, which can explain their higher occurrence in acid soils in the Vosges context. However, they can grow in a wide range of mineral soil conditions (i.e. base saturation ratio and $\mathrm{pH}$ ) in other mountainous areas and in particular in the inner Alps [7, 33, 52]. In this area, it has been shown that, in contrast to the Vosges mountains, the available $\mathrm{N}$ and $\mathrm{P}$ content can be low in neutral and basic soils as well as in very acidic soils [50]. The consistency between our field results and those provided by previous field studies and experiments suggests that the different responses of tree species according to mineral soil characteristics can be extended over the Vosges Mountains context.

Nutritional behaviour was related to climatic behaviour for some tree species, such as sycamore, which is present in negative water balance sites only in areas with high nutritional levels. On the contrary, this species is present throughout the entire nutrient gradient for high water balance conditions. This can be explained by the strong competition from hornbeam, ash and sessile oak in sites with low water availability (at low elevation). The taking into account of both nutrient and climatic effects on species distribution provides a better understanding of their response to environmental factors.

\subsection{Efficiency of measured and estimated variables to explain tree species occurrence}

Plant bioindication of ecological factors has been traditionally widely used by forest managers to assess site quality, particularly soil moisture and nutrient availability, in order to satisfy sustainable management objectives $[8,16,69,72]$. The herbaceous vegetation was also used in forest management to predict tree species productivity, either directly [40, 53], after a multivariate analysis [54] or using ecological groups of plant species [68]. Our study tested the efficiency of understory vegetation to predict stand composition and occurrence probability of native commercial tree species, which is also of great importance in forest management.

Understory vegetation, through CA sites scores, Ellenberg or EcoPlant indicator values, gave results that were as effective as measured ecological variables to predict forest composition or species niche. Indicator values established on a national scale, such as indicator values from EcoPlant database or Ellenberg indicator values, seem to be more interesting than multivariate ordination scores extracted from regional floristic analysis, because they can be used over a broader area with a fairly similar efficiency. The formalization and reproducibility of EcoPlant IV construction represent their main interest as compared to Ellenberg values. The high level of IV efficiency confirms the approaches of Diekmann [18] and Laweson and Oksanen [42], who derived the nutritional realized niche of tree species using plant indicator characteristics. The estimation of nutrient availability in sites using the plant indicator approach, matched with GIS extraction of climatic variables, would allow the use of numerous plots to assess realized niche of tree species over wide areas according to the main ecological factors.

Acknowledgements: The authors wish to thank J.-C. Hervé for his help and useful suggestions on an earlier version of this manuscript, as well as D. Lopez and anonymous reviewers for their appropriate comments. This study was financed through grant to Paulina Pinto by the French Government. EcoPlant is a phytoecological database supported by the French Institute of Agricultural Forest and Environmental Engineering (ENGREF), the French Ministry of Agriculture (DERF) and the French Agency for Environment and Energy Management (ADEME).

\section{REFERENCES}

[1] Akaike H., Information theory as an extension of the maximum likelihood principle, in: Petrov B.N., Csaki F. (Eds.), Second Symposium on Information Theory, Akademiai Kiai, Budapest, 1973, pp. 267-281.

[2] André F., Ponette Q., Comparison of biomass and nutrient content between oak (Quercus petraea) and hornbeam (Carpinus betulus) trees in a coppice-with-standards stand in Chimay (Belgium), Ann. For. Sci. 60 (2003) 489-502.

[3] Augusto L., Ranger J., Ponette Q., Rapp M., Relationships between forest tree species, stand production and stand nutrient amount, Ann. For. Sci. 57 (2000) 313-324. 
[4] Austin M.P., Spatial prediction of species distribution: An interface between ecological theory and statistical modelling, Ecol. Model. 157 (2002) 101-118.

[5] Austin M.P., Meyers J.A., Current approaches to modelling the environmental niche of eucalyptus: implication for management of forest biodiversity, For. Ecol. Manage. 85 (1996) 95-106.

[6] Austin M.P., Cunningham R.B., Fleming P.M., New approaches to direct gradient analysis using environmental scalars and statistical curve-fitting procedures, Vegetatio 55 (1984) 11-27.

[7] Bartoli C., Étude écologique sur les associations forestières de la Haute-Maurienne, Ann. Sci. For. 23 (1966) 432-761.

[8] Becker M., Le Goff N., Diagnostic stationnel et potentiel de production, Rev. For. Fr. 40 (1988) 29-43.

[9] Benichou P., Le Breton O., Prise en compte de la topographie pour la cartographie des champs pluviométriques statistiques, Météorologie 7 (1987) 23-34.

[10] Bergmeier E., Dimopoulos P., Fagus sylvatica forest vegetation in Greece: Syntaxonomy and gradient analysis, J. Veg. Sci. 12 (2001) 109-126.

[11] Bolliger J., Kienast F., Zimmermann N.E., Risks of global warming on montane and subalpine forests in Switzerland - a modeling study, Reg. Environ. Change. 1 (2000) 99-111.

[12] Bonneau M., Evolution of the mineral fertility of an acidic soil during a period of ten years in the Vosges mountains (France). Impact of humus mineralisation, Ann. For. Sci. 62 (2005) 253-260.

[13] Brêthes A., Brun J.J., Jabiol B., Ponge J.F., Toutain F., Classification of forest humus forms: a French proposal, Ann. Sci. For. 52 (1995) 535-546.

[14] Brunet J., Falkengren-Grerup U., Tyler G., Pattern and dynamics of the ground vegetation in south Swedish Carpinus betulus forests: Importance of soil chemistry and management, Ecography 20 (1997) 513-520.

[15] Cachan P., Étude bioclimatique du Massif Vosgien, Bull. E.N.S.A.I.A. Nancy 16 (1974) 1-45.

[16] Cajander A.K., The theory of forest types, Acta For. Fenn. 29 (1926) 1-108.

[17] De Martonne E., Une nouvelle fonction climatologique: l'indice d'aridité, Météorologie 2 (1926) 449-458.

[18] Diekmann M., Ecological behaviour of deciduous hardwood trees in Boreo-nemoral Sweden in relation to light and soil conditions, For. Ecol. Manage. 86 (1996) 1-14.

[19] Diekmann M., Species indicator values as an important tool in applied plant ecology: A review, Basic Appl. Ecol. 4 (2003) 493506.

[20] Diekmann M., Falkengren-Grerup U., A new species index for forest vascular plants: development of functional indices based on mineralization rates of various forms of soil nitrogen, J. Ecol. 86 (1998) 269-283.

[21] Duchaufour P., Pédologie et groupes écologiques. I. Rôle du type d'humus et du pH, Bull. Ecol. 20 (1989) 1-6.

[22] Duchaufour P., Pédologie et groupes écologiques. II. Rôle des facteurs physiques : aération et nutrition en eau, Bull. Ecol. 20 (1989) 99-107.

[23] Duchaufour P., Toutain F., Apport de la pédologie à l'étude des écosystèmes, Bull. Ecol. 17 (1985) 1-9.

[24] Elgersma A.M., Dhillion S.S., Geographical variability of relationships between forest communities and soil nutrients along a temperature-fertility gradient in Norway, For. Ecol. Manage. 158 (2002) 155-168.

[25] Ellenberg H., Vegetation ecology of Central Europe, Cambridge University Press, Cambridge, 1988.

[26] Ellenberg H., Weber H.E., Düll R., Wirth V., Werner W., Paulißen D., Zeigerwerte von Pflanzen in Mitteleuropa, 1992.

[27] Falkengren-Grerup U., Brunet J., Quist M.E., Sensitivity of plants to acidic soils exemplified by the forest grass Bromus benekenii, Water Air Soil Pollut. 85 (1995) 1233-1238.
[28] Ferris R., Peace A.J., Humphrey J.W., Broome A.C., Relationships between vegetation, site type and stand structure in coniferous plantations in Britain, For. Ecol. Manage. 136 (2000) 35-51.

[29] Gégout J.-C., Étude des relations entre les ressources minérales du sol et la végétation forestière dans les Vosges, thèse de l'Université de Nancy I, Nancy, 1995, 215 p.

[30] Gégout J.-C., Houllier F., Canonical correspondance analysis for forest site classification. A case study, Ann. Sci. For. 53 (1996) 981-990.

[31] Gégout J.-C., Coudun C., Brisse H., Bergès L., Comportement écologique des espèces forestières vis-à-vis du climat et du sol en France: application à l'évaluation des charges critiques d'acidité et d'azote, Rapport final de la convention de recherche ADEM/ ENGREF n ${ }^{\circ}$ 9962003, ENGREF, Nancy-France, 2002, 51 p.

[32] Gégout J.-C., Coudun C., Bailly G., Jabiol B., EcoPlant: A forest site database linking floristic data with soil and climatic variables, J. Veg. Sci. 16 (2005) 257-260.

[33] Gensac P., Les forêts d'épicéa de Tarentaise. Recherche de différents types de Pessières, Rév. Gén. Bot. 74 (1967) 425-528.

[34] Graae B.J., Heskjaer V.S., A comparison of understorey vegetation between untouched and managed deciduous forest in Denmark, For. Ecol. Manage. 96 (1997) 111-123.

[35] Guisan A., Zimmermann N.E., Predictive habitat distribution models in ecology, Ecol. Model. 135 (2000) 147-186.

[36] Hagen-Thorn A., Armolaitis K., Callesen I., Stjernquist I., Macronutrients in tree stems and foliage: a comparative study of six temperate forest species planted at the same sites, Ann. For. Sci. 61 (2004) 489-498.

[37] Härdtle W., Von Oheimb G., Westphal C., The effects of light and soil conditions on the species richness of the ground vegetation of deciduous forests in northern Germany (Schleswig-Holstein), For. Ecol. Manage. 182 (2003) 327-338.

[38] Iverson L.R., Prasad A.M., Predicting abundance of 80 tree species following climate change in the eastern United States, Ecol. Monogr. 68 (1998) 465-485.

[39] Klinka K., Wang Q., Carter R.E., Relationships among humus forms, forest floor nutrient properties, and understory vegetation, For. Sci. 36 (1990) 564-581.

[40] Lahti T., Understorey vegetation as an indicator of forest site potential in southern Finland, Acta For. Fenn. 246 (1995) 2-69.

[41] Landolt E., Ökologische zeigerwerte zur Schweizer flora, Veröff. Geobot. Inst. ETH, Zürich, 1977.

[42] Lawesson J.E., Oksanen J., Niche characteristics of Danish woody species as derived from coenoclines, J. Veg. Sci. 13 (2002) 279290.

[43] Leathwick J.R., Austin M.P., Competitive interactions between tree species in New Zealand's old growth indigenous forests, Ecology 82 (2001) 2560-2573.

[44] Lebreton J.D., Chessel D., Prodon R., Yoccoz N., L'analyse des relations espèces-milieu par l'analyse canonique des correspondances. I. Variables de milieu quantitatives, Acta Oecol. 9 (1988) 53-67.

[45] Lenihan J.M., Ecological response surfaces for North American boreal tree species and their use in forest classification, J. Veg. Sci. 4 (1993) 667-680.

[46] Mathsoft I., S-Plus 2000, Programmer's Guide, MathSoft, Inc., Seattle, 1999.

[47] Mayer H., Waldbau auf sociologisch-ökologischer Grundlage, Gustav Fisher, Stuttgart, Germany, 1992.

[48] Mccullagh P., Nelder J.A., Generalized linear models, Chapman \& Hall, London, UK, 1989.

[49] Mckenzie D., Peterson D.W., Peterson D.L., Thornton P.E., Climatic and biophysical controls on conifer species distributions in mountain forests of Washington State, USA, J. Biogeogr. 30 (2003) 1093-1108.

[50] Michalet R., Gandoy C., Joud D., Pages J.P., Choler P., Plant community composition and biomass on calcareous and siliceous substrates in the northern French Alps: Comparative effects of soil chemistry and water status, Arct. Antarct. Alp. Res. 34 (2002) 102-113. 
[51] Michalet R., Rolland C., Joud D., Gafta D., Callaway R.M., Associations between canopy and understory species increase along a rainshadow gradient in the Alps: habitat heterogeneity or facilitation? Plant Ecol. 165 (2002) 145-160.

[52] Michalet R., Cadel G., Joud D., Pache G., Pautou G., Richard L., Synthèse phytoécologique des forêts de l'arc alpin, Ecologie 29 (1998) 99-104.

[53] Nieppola J., Understorey plants as indicators of site productivity in Pinus sylvestris L. stands, Scand. J. For. Res. 8 (1993) 49-65.

[54] Nieppola J., Carleton T.J., Relations between understorey vegetation, site productivity, and environmental factors in Pinus sylvestris L. stands in southern Finland, Vegetatio 93 (1991) 52-72.

[55] Ohmann J.L., Spiess T.A., Regional gradient analysis and spatial pattern of woody plant communities of Oregon forests, Ecol. Monogr. 68 (1998) 151-182.

[56] Pagès J.P., Pache G., Joud D., Magnan N., Michalet R., Direct and indirect effects of shade on four forest tree seedlings in the French Alps, Ecology 84 (2003) 2741-2750.

[57] Prodon R., Lebreton J.-D., Breeding avifauna of a Mediterranean succession: the holm oak and cork oak series in the eastern Pyrénées. 1. Analysis and modelling of the structure gradient, Oikos 37 (1981) 21-38.

[58] Rameau J.-C., Mansion D., Dumé G., Flore forestière française. Guide écologique illustré. Tome 2 : Montagnes, Institut pour le Développement Forestier, Paris, 1993.

[59] Rameau J.-C., Mansion D., Dumé G., Timbal J., Lecointe A., Dupont P., Keller R., Flore forestière française. Guide écologique illustré. Tome 1 : Plaines et collines, Institut pour le Développement Forestier, Paris, 1989.

[60] Roche P., Tatoni T., Médail F., Relative importance of abiotic and land use factors in explaining variation in woody vegetation in a French rural landscape, J. Veg. Sci. 9 (1998) 221-228.

[61] Rol R., Contribution à l'étude de la répartition du sapin (Abies alba Mill.), Ann. Éc. Natl. Eaux For. 7 (1937) 1-68.
[62] Sverdrup H., Warfvinge P., The effect of soil acidification on the growth of trees, grass and herbs as expressed by the $(\mathrm{Ca}+\mathrm{Mg}+\mathrm{K}) /$ Al ratio, Lund University, Department of Chemical Engineering, Lund-Sweden, 1993, 108 p.

[63] Ter Braak C.J.F., Canonical correspondence analysis: a new eigenvector technique for multivariate direct gradient analysis, Ecology 67 (1986) 1167-1179.

[64] Ter Braak C.J.F., Barendregt L.G., Weighted averaging of species indicator values: its efficiency in environmental calibration, Math. Biosci. 78 (1986) 57-72.

[65] Ter Braak C.J.F., Looman C.W.N., Weighted averaging, logistic regression and the Gaussian response model, Vegetatio 65 (1986) 3-11.

[66] Ter Braak C.J.F., Prentice I.C., A theory of gradient analysis, Adv. Ecol. Res. 18 (1988) 271-317.

[67] Thornthwaite C.W., Mather J.R., Instructions and tables for computing potential evapotranspiration and the water balance, Publications in Climatology 10 (1957) 183-311.

[68] Wang G.G., White spruce site index in relation to soil, understory vegetation, and foliar nutrients, Can. J. For. Res. 25 (1995) 29-38.

[69] Wang G.G., Use of understory vegetation in classifying soil moisture and nutrient regimes, For. Ecol. Manage. 129 (2000) 93-100.

[70] Wartenberg D., Ferson F., Rohlf F., Putting things in order: A critique of detrended correspondence analyses, Am. Nat. 129 (1987) 434-448.

[71] Weber-Blasschke G., Claus M., Rehfuess K.E., Growth and nutrition of ash (Fraxinus exelsior $\mathrm{L}$.) and sycamore (Acer pseudoplatanus L.) on soils of different base saturation in pot experiments, For. Ecol. Manage. 167 (2002) 43-56.

[72] Wilson S.M., Pyatt D.G., Malcolm D.C., Connolly T., The use of ground vegetation and humus type as indicators of soil nutrient regime for an ecological site classification of British forests, For. Ecol. Manage. 40 (2001) 101-116. 